\title{
Analysis of occupational performance for the promotion of health in people with fibromyalgia. A phenomenological study
}

Análisis del desempeño ocupacional para la promoción de la salud en personas con fibromialgia. Un estudio fenomenológico

\author{
Alicia Sixto Sueiras ${ }^{\mathrm{a}}$, Ana-Isabel Souto-Gómez ${ }^{\mathrm{b}}$, Miguel-Ángel Talavera- \\ Valverde ${ }^{\mathrm{c}}$ \\ a Programa de especialización Máster en Discapacidad y Dependencia. Universidad de A Coruña, A \\ Coruña, Spain \\ $b$ Escuela Universitaria de Trabajo Social, Universidad de Santiago de Compostela. Federación Galega de \\ Esclerose Múltiple (FEGADEM), Santiago de Compostela, A Coruña, Spain \\ c Unidad de investigación Integra Saúde, Departamento Ciencias de la Salud, Universidade da Coruña, \\ Xerencia de Xestión Integrada de Ferrol, Ferrol, A Coruña, Spain
}

\begin{abstract}
Introduction

An imbalance in the performance or occupational participation can be detrimental to health. To a large extent, this is the case in people diagnosed with fibromyalgia.
\end{abstract}

Objective

This research study was carried out in order to determine the occupational performance in people diagnosed with fibromyalgia in the Galician province of A Coruña (Spain).

Material and methods

A qualitative methodology was used, with data being collected through semi-structured interviews and a field notebook. A total of 34 people participated, including those diagnosed, family members and professionals. 
Results

Four themes were identified: (1) «everything costs», (2) «only I know what I can do», (3) «if I don’t feel well, I stay», (4) «either they get help or breakdown».

\section{Conclusion}

Following the diagnosis of fibromyalgia people change the characteristics of their occupational performance, both terms of influencing factors, in the way they conduct their activities, and in terms of their environments.

\section{Resumen}

Introducción

Un desequilibrio en el desempeño o en la participación ocupacional puede provocar una falta de salud, y esta situación se encuentra en una gran medida en las personas diagnosticadas de fibromialgia.

\section{Objetivo}

El presente estudio de investigación se realizó con el fin de conocer cómo es el desempeño ocupacional en personas diagnosticadas de fibromialgia en la provincia gallega de A Coruña (España).

\section{Materiales y métodos}

Se utilizó una metodología cualitativa, se recogieron datos mediante la realización de entrevistas semiestructuradas y de un cuaderno de campo. Participaron 34 individuos, entre personas diagnosticadas, familiares y profesionales.

\section{Resultados}

Surgieron cuatro temáticas: (1) «todo cuesta»; (2) «solo yo sé lo que puedo hacer»; (3) «si no estoy bien, me quedo», y (4) «las apoyan o nada».

\section{Conclusión}

Las personas con fibromialgia tras el diagnóstico ven modificadas las características de su desempeño ocupacional, tanto en factores influyentes, en la forma de realizer las actividades, como en los entornos.

\section{Keywords}

Occupational performance; Fibromyalgia; Health promotion; Health; Occupational therapy

\section{Palabras clave}

Desempeño ocupacional; Fibromialgia; Promoción de salud; Salud; Terapia ocupacional 


\section{Introduction}

The World Health Organization (WHO) defines health as "a state of complete physical, mental and social well-being and not merely the absence of disease or infirmity". ${ }^{1}$ The WHO conceives health a means to accomplish a dignified and productive life, ${ }^{2}$ emphasizing the positive aspect of this term and the relationship of the individual with his/her environment. ${ }^{3}$ The Ottawa Charter for the Promotion of Health highlights occupational performance and participation as factors that are beneficial for people's health and wellbeing. ${ }^{4}$

\section{Occupation and health}

Occupation is the activity whereby the individual relates to his/her environment, ${ }^{5}$ and is based on three levels: (a) occupation as an agent of change of the somatic and psychic characteristics of the individual; (b) the ability of the individual to adapt to the environment or to adapt the environment to him/herself; (c) occupation as therapy. ${ }^{6}$ This latter concept relates to occupational therapy (a profession focusing on the promotion of health and wellbeing through occupation). ${ }^{7}$ Therefore, we may highlight occupational therapy intervention -which works through occupationas a procedure become healthy through occupational performance.

Occupational performance is defined as the ability to perform and complete a particular task as a result of a dynamic transaction between the individual, the context/environment and the activity. ${ }^{5}$ In other words, any activity that involves participating being occupied (self-care, instrumental daily life tasks, rest and sleep, work, education, leisure, and social participation $)^{5}$ and being healthy. ${ }^{7}$ Hence, inactivity may compromise personal health. ${ }^{8}$

In terms of occupational performance and occupational therapy, the latter professional discipline is the most appropriate intervention when both occupation and health are compromised.

\section{Occupational performance of individuals with a diagnosis of fibromyalgia}

Health and occupation must work together, otherwise the result is an imbalance in occupational performance as is the case in people with a diagnosis of fibromyalgia.

Fibromyalgia is generalized chronic pain in the fibrous tissues of the body, in the absence of proven organic dysfunction. One of the most relevant characteristics of fibromyalgia is the presence of tender points. ${ }^{9}$ Other symptoms include: stiffness, fatigue, insomnia, abdominal discomfort and hypersensitivity, inter alia. ${ }^{10}$

The prevalence of fibromyalgia in Spain is of $2.4 \%,{ }^{11}$ with a proportion of $7-9$ females per each male diagnosed. ${ }^{9,12}$

This pathology results in a significant impact on society because, among other factors, these patients must be assisted to perform their regular activities, ${ }^{13},{ }^{14}$ high rates of absenteeism, ${ }^{12}$ high medical costs, ${ }^{15}$ and in general excessive number of consultations. ${ }^{16}$

Due to all of these factors, and with a view to further elaborate on this topic, our general objective is to study the occupational performance of people diagnosed with fibromyalgia. The specific objectives are: (a) to explore que basic characteristics of occupational performance; (b) learn about the individual performance-related characteristics, (c) analyze the individual environments, and (d) identify the lifestyles, roles and routines of occupational performance. 


\section{Materials and methods}

Study design

We tried to look for the human experience in every context and wanted to learn about the vision of people diagnosed with fibromyalgia about their everyday life; hence, we framed our qualitative research ${ }^{17}$ within a phenomenological theoretical-methodological perspective. ${ }^{18}$

We integrated our research within a constructive-interpretative methodological paradigm, ${ }^{19}$ and a contemporary paradigm of the profession, ${ }^{20}$ from the occupation therapy perspective.

\section{Participants}

The study was conducted in the A. Coruña Province because this region has the largest number of Associations in Galicia (five associations).

To select the population, we implemented an intentional open theoretical sampling ${ }^{21}$ with the participation of the individuals that met the selection criteria (Table 1). Moreover, in order to accomplish the research objective, (study the occupational performance of the people diagnosed with fibromyalgia), a triangulation by informants was conducted. ${ }^{19}$ The purpose of such triangulation is not to compare results, but rather to enrich and contrast the information provided by the participants diagnosed with fibromyalgia that are the object of this study. ${ }^{19}$ The vortices of the triangulation were: individuals diagnosed with fibromyalgia, family members of patients, and healthcare professionals in the third sector working with fibromyalgia patients (Table 1).

Table 1. Sample selection criteria

\begin{tabular}{|c|c|}
\hline Inclusion & Exclusion \\
\hline \multicolumn{2}{|l|}{ Persons diagnosed with fibromyalgia } \\
\hline $\begin{array}{l}\text { Age equal or more than } 18 \text { years } \\
\text { Be registered in the Municipal Census of } 2018 \text { in the Province } \\
\text { of A Coruña } \\
\text { Having lived in such area for at least } 5 \text { years } \\
\text { Being diagnosed for more than one year }\end{array}$ & $\begin{array}{l}\text { Present health problems that impair data collection. Have a } \\
\text { different diagnosis than may interfere with occupational } \\
\text { performance. } \\
\text { Not having a medical diagnosis of fibromyalgia }\end{array}$ \\
\hline \multicolumn{2}{|l|}{ Relatives } \\
\hline $\begin{array}{l}\text { Be a blood relative, affinity or adoption up to the third degree } \\
\text { of consanguinity, spouse, or in-law of a relative with } \\
\text { fibromyalgia. }\end{array}$ & $\begin{array}{l}\text { Having a health condition that impairs data collection } \\
\text { Not living in the same domicile of the person diagnosed with } \\
\text { fibromyalgia over the course of one year prior to the } \\
\text { interview }\end{array}$ \\
\hline \multicolumn{2}{|l|}{ Professionals working in third sector activities } \\
\hline At least 18 years old & \\
\hline $\begin{array}{l}\text { Individuals working in agencies associated with } \\
\text { rheumatological diseases in the A Coruña } \\
\text { Province People working in agencies with headquarters in the } \\
\text { A coruña province }\end{array}$ & $\begin{array}{l}\text { Having health problems that impair data collection } \\
\text { Professionals with less than } 5 \text { year experience in fibromyalgia } \\
\text { People that do not work for public or private institutions }\end{array}$ \\
\hline
\end{tabular}


The final number of informants was $n=34$ (Table 2). We were able to access these people through a liaison person ${ }^{19}$ (an individual who controlled field access, authorizing and facilitating our entrance, assisted in identifying the participants, but did not influence the selection). We discontinued the recruitment process after reaching the theoretical saturation. ${ }^{22}$

Table 2. Description of informants.

\begin{tabular}{|c|c|c|c|c|c|c|}
\hline Code & Sex & Age & Nationality & Place of Residence & Institution & Role \\
\hline UAC0150M & M & 50 & Spanish & A Coruña & ACOFIFA & User \\
\hline UAC0255M & M & 55 & Spanish & A Coruña & ACOFIFA & User \\
\hline UAC0366M & M & 66 & Spanish & A Coruña & ACOFIFA & User \\
\hline UFI0452M & M & 52 & Spanish & Arteixo & FIBROARTEIXO & User \\
\hline UFI0548M & M & 48 & Spanish & Lañas & FIBROARTEIXO & User \\
\hline FFI0666M & M & 66 & Spanish & Arteixo & FIBROARTEIXO & Relative \\
\hline UFI0743M & M & 43 & Spanish & Arteixo & FIBROARTEIXO & User \\
\hline UFI0844M & M & 44 & Spanish & Arteixo & FIBROARTEIXO & User \\
\hline FFI0958H & $\mathrm{H}$ & 58 & Spanish & Arteixo & FIBROARTEIXO & Relative \\
\hline PAF1048M & M & 48 & Spanish & Ferrol & AFFINOR & Professional \\
\hline UAF1154M & M & 54 & Spanish & Ferrol & AFFINOR & User \\
\hline UAF1242M & M & 42 & Spanish & Ferrol & AFFINOR & User \\
\hline UAF1355M & M & 55 & Spanish & Ferrol & AFFINOR & User \\
\hline UAF1467M & M & 67 & Spanish & Caranza & AFFINOR & User \\
\hline UAF1560M & M & 60 & Spanish & Caranza & AFFINOR & User \\
\hline UAF1677M & M & 77 & Spanish & Ferrol & AFFINOR & User \\
\hline UAF1736M & M & 36 & Spanish & Valdoviño & AFFINOR & User \\
\hline FAF1819M & M & 19 & Spanish & Catabois & AFFINOR & Relative \\
\hline UAF1919M & M & 19 & Spanish & Catabois & AFFINOR & User \\
\hline UAF2057M & M & 57 & Spanish & Ferrol & AFFINOR & User \\
\hline PAF2145M & M & 45 & Spanish & Narón & AFFINOR & Professional \\
\hline UAF2258M & M & 58 & Spanish & Esteiro & AFFINOR & User \\
\hline UAF2365M & M & 65 & Spanish & Cedeira & AFFINOR & User \\
\hline FAF2465M & M & 65 & Spanish & Valdoviño & AFFINOR & Relative \\
\hline UAF2557M & M & 57 & Spanish & Fene & AFFINOR & User \\
\hline UAF2654M & M & 54 & Spanish & Narón & AFFINOR & User \\
\hline PAF2745M & M & 45 & Spanish & Ferrol & AFFINOR & Professional \\
\hline UAF2853M & M & 53 & Spanish & Caranza & AFFINOR & User \\
\hline FAF2954H & $\mathrm{H}$ & 54 & Spanish & Caranza & AFFINOR & Relative \\
\hline PAF3038M & M & 38 & Spanish & Ferrol & AFFINOR & Professional \\
\hline FAF3122H & $\mathrm{H}$ & 22 & Spanish & A Coruña & AFFINOR & Relative \\
\hline UAF3269M & M & 69 & Spanish & A Coruña & AFFINOR & User \\
\hline PAC3327M & M & 27 & Spanish & Coruña & ACOFIFA & Professional \\
\hline PAF3435M & M & 35 & Spanish & Narón & AFFINOR & Professional \\
\hline
\end{tabular}

\section{Procedure}

The research was conducted between October 2017 and June 2018 and we had the favorable report of the Galician Ethics in Research Committee (2018/124). Thanks to the Liaison person we had the support of the chairpersons of the Board of Directors of the third sector organizations. We applied for the corresponding access permits and upon these were granted, we contacted the potential participants that met the selection criteria.

Additionally, the sample was completed using the "snowball" strategy. ${ }^{18}$ After identifying the key participants we used this strategy to ask them if they knew other people with the same profile that could also participate. We then contacted these people and upon ensuring compliance with the selection criteria, we proceeded to include them in the research. We used this strategy because this is one of the best techniques to reach difficult to access or hidden populations. ${ }^{19}$ All the individuals who voluntarily accepted to participate, received an information brochure and signed an informed consent endorsing their participation. 


\section{Data collection}

We used in depth interviewing and field notebook. To protect participants' privacy, we assigned an alphanumeric code to each participant ${ }^{19}$ based on the following order: (a) the triangulation group they belong to: $U$ (individual diagnosed with fibromyalgia); F (family member); P (professionals); (b) membership: AC (ACOFIFA); FI (FIBROARTEIXO); AF (AFFINOR); (c) participant number; (d) age; (e) sex; (f) localization of the verbatim in the transcription (page and line (s)). The interview recordings (audios) were made using a digital recorder. Then the recordings were exactly transcribed, together with the sociodemographic profile. Notes were entered into the field notebook just before the start of the interview and at the end of each interview. We made methodological, theoretical and descriptive notes per event, topic and period of time.

\section{Analysis of the data}

We used an inductive approach,19 doing an independent analysis using the Atlas Ti 6.0 software and organized data codes comparing notes and interpretations to reach a consensus. The units were compiled into categories and then into topics. Different theoretical approaches were used based on the results, since there were no pre-established methodologies.19 At the end of the exercise, all recordings and transcriptions were destroyed.

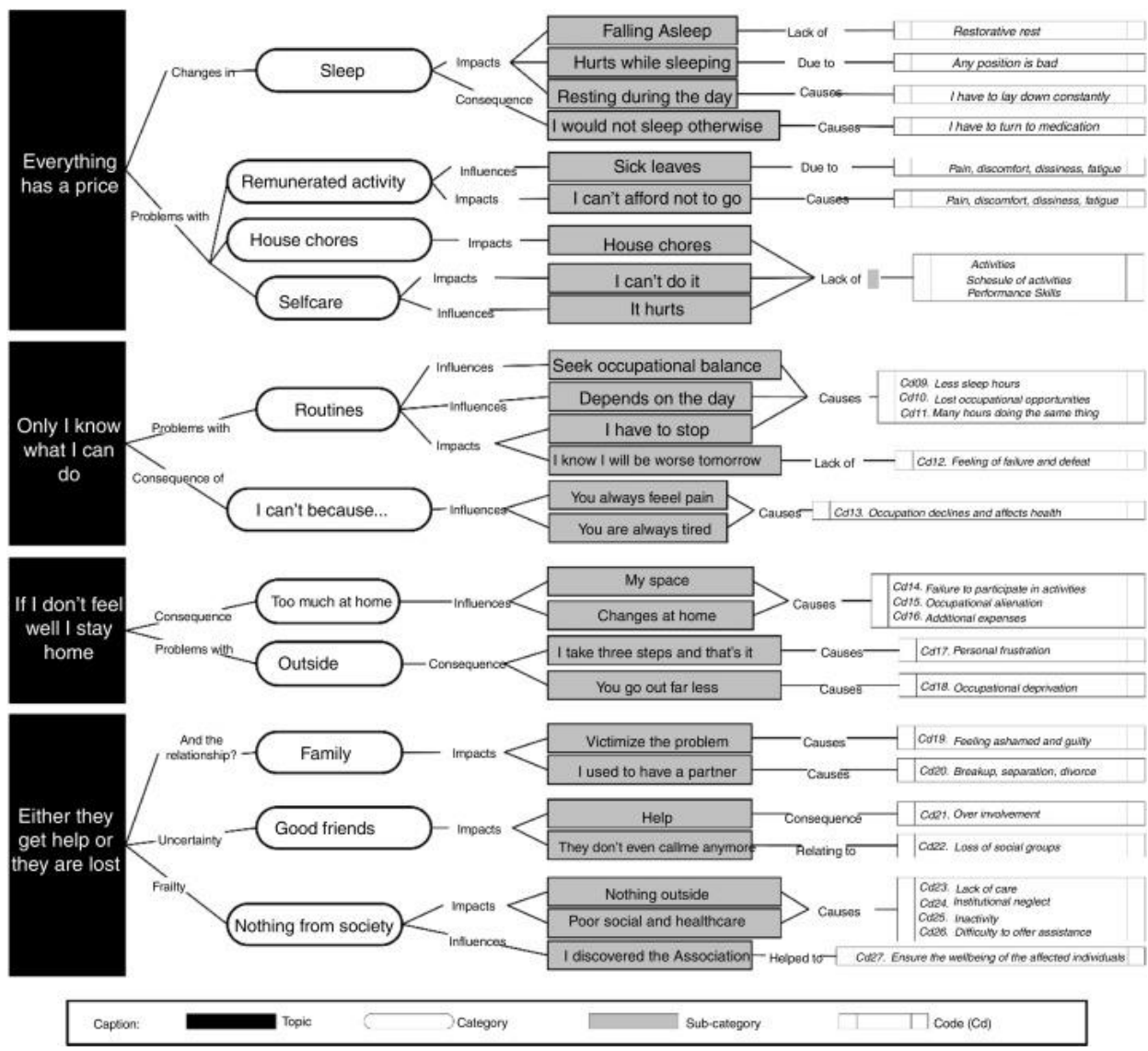

Fig. 1. Correspondence among topics, categories, sub-categories and codes, identified based on the analysis of the data collected during the research project. 


\section{Results}

The results indicated a change in occupational performance of individuals before vs. after they were diagnosed with fibromyalgia (Fig. 1). The results included the verbatim of each vortex in order to enrich and contrast the information of the people with a diagnosis of fibromyalgia, rather than to compare points of view.

\section{Everything has a cost}

Occupational performance issues were experienced in activities of daily living, highlighting rest-related experiences: 31)

«And hours of sleep, these are individuals that have trouble falling asleep.» (PAF3038 M.2.30-

They say they take medicine to reduce pain and be able to sleep:

«I am takin 13 pills in total... these pills help me to go to sleep.» (UFI0743 M.1.18-21)

They underlined night panic, fear of the pain they may experience for hours, misery over a sleepless night, inability to manage the physical space of the bedroom or difficulties to adopt a position that avoided pain:

«In terms of sleeping, most days he/she sleeps in the sofa, because it is impossible to sleep in the bed, unable to find the proper body position; it is constant pain.» (FAF1819 M.1.16-19)

The lack of rest and accumulated tiredness make it difficult to perform the normal everyday activities, and requires them to sleep during the daytime:

«I may get out of bed at around 9 a.m., but by eleven I am already so tired and sleepy that I sleep until around one or two in the afternoon... Then in the afternoon, by 4 p.m., again I feel tired and sleepy and I wake up around eight until midnight and the cycle repeats.» (UAF1154 M.5.117125)

Along these lines, the second most difficult to perform activity is work. Although there are some people that go on working just as they did prior to being diagnosed, many people have to make changes in their activities, claiming that they experience an increased need to leave their workplace or ask for a leave absence:

«I had to quit my job because I was always on a leave of absence; I could work maybe fifteen days and had three months leave; I was so mad, the day I came back to work I was unable to sleep because of pain.» (UAC0150 M.3.53-56)

However, this population cannot afford not to work because they need the money and this results in several issues:

«There is a small percentage of people that works eight hours every day... and refer constant pain.» (PAF3038 M.1.23-24)

This is also an issue for house chores. Cleaning, shopping, or cooking are all very painful activities, particularly because they involve using their arms and frequently raising them:

«At home, she does not do that anymore, even when she feels ashamed of having the place in such condition and that causes additional stress, but she cannot do it anymore.» (FAF1819 M.1.911)

The pain is even present in selfcare activities: 
«Washing your hair, raising your arms is so painful; she used to have long hair but decided to cut it short because of her inability to comb her hair.» (FAF1819 M.2.27-29)

This pain forces patients to make changes in their daily routine and even change activities, particularly recreational activities to focus on more relaxed activities that physically less demanding.

«They do less things and limit themselves when performing certain activities... gymnastics, walks, workshops... they hold back their activities even beyond what their disease requires.» (PAF3038 M.2.42-45)

Moreover, pain makes then change their habits and routines:

«Very frequently when I am walking, I stop in front of shop windows (I didn't do that before), but I don't do it to see the window display, I stop to take a break.» (UAF2057 M.4.96-99)

Only I know what I am able to do

A first group needs to structure routines in order to move on with their daily life:

«I think that routines are strongly established, though this depends on each individual person.» (PAF2145 M.5.127-128)

A second group usually begins by saying "that depends" and they wait to the last minute before doing an activity to decide whether to cancel or not:

«I used to be very busy every day, but not anymore; there are days in which I can't move, and others in which I feel find. But then, since I feel well, I overdo it.» (UAF1154 M.4.93-97)

Over the course of the day, they even need to stop the routine and think about the consequences of what they are doing, which limits their performance versus what they used to do:

«As soon as you exceed the limits you will then spend three days in bed. Initially I don't realize what I am doing, but after one hour I start noticing symptoms and now I messed up again. What happened? I let myself go out of excitement.» (UAC0255 M.4.96-101)

The tiredness and the pain, again limit my performance and occupational skills:

«Fibromyalgia is a complicated issue because it is a persistent pain which prevents you from doing your normal activities.» (PAF2145 M.1.3-5)

This forces them to take breaks:

«It is too time consuming, I can see that; what I used to do very quickly, now takes me twice as much; it hurts, so I have to stop, I feel tired and fatigued.» (UFI0452 M.1.18-20)

\section{If I don't feel well, I just stay home}

Usually they just don't go out as often and their physical environment becomes their comfort zone, adapted to their needs (and involves some expenses):

«Some furniture had to be adapted to her: the bed, the sofa...» (FAF2954H.2.30-32)

Pain and fatigue limit the number of times they go out and they mostly stay home: 
«The people I know continue to go out, but much less; if they go out today, tomorrow they stay home because they can't stand it anymore.» (PAF2145 M.4.104-106)

\section{Either they get help, or breakdown}

The social environment of individuals with fibromyalgia (families, friends, professional healthcare resources) will be crucial in terms of their absence or daily life relevance:

«The relationship is no longer the same because I can no longer do the things I used to do.» (UFI0548 M.4.95-97)

Moreover, the same happens with friends; some people with fibromyalgia feel the need to breakup with their family environment:

«As a result of the disease everything was disrupted and vanished, even my partner.» (UAC0255 M.1.15-16)

There may even be two contrasting situations; either your friends provide total support:

«It is indeed true that some of the people surrounding her stopped calling her to share a cup of coffee or any other activity; but her lady friends, her real old friends, are still there.» (FAF3122H.2.28-31) disease:

... or just breakup because of their inability to understand the everyday consequences of the

«The fact that you cannot lead a normal life is not understood by society, your parents, or partner; whichever the reason.» (PAF2145 M.3.79-81)

And to conclude, there are two salient negative factors; pity for yourself:

«And then, sometimes pity; you should not feel sorry for anyone... I have what I have and I do what I do, but well this is how it is.» (FAF2954H.4. 96-99)

... and barriers in public services (social and health), so the last resource is associations.

«This is a barely visible disease, so there is little social support; the only option is an association that offers rehabilitation therapies.» (FAF3122H.1.27-30).

\section{Discussion}

The results show that most occupational areas (selfcare, instrumental daily life activities, rest and sleep, work, education, leisure and social participation)5 experience changes; some activities are discontinued because of generalized pain, low energy levels, poor motivation and fatigue. We are aware that occupational performance is indivisible, but in order to explain the impact of the changes experienced, the decision was made to explain them separately into two findings.

The primary finding shows occupational performance with a decline in the number of activities performed due to physical, social, and psychological factors, similar to another study ${ }^{23}$ assessing the quality of life-related characteristics of the disease (physical discomfort, depression, selfefficacy, and social support). One of the factors that impacts occupational performance is the organic consequences of the disease, reflected on household chores, work and leisure activities, as well as the ability to rest. 
Numerous studies emphasize the need to have healthy rest and sleep in order to be able to perform our regular activities, ${ }^{24,25}$ but this is not our case, since most people experience sleeping difficulty as an issue that is consistent with the results of other research studies ${ }^{26}$; sleep-associated disorders seem to be one of the most relevant problems and are considered part of cognitive disorders with significant impact on memory and affective behavior. Furthermore, in our studies, participants claim that pain worsens during the night time, making it difficult to fall asleep (which is similar in other studies), ${ }^{27,} 28$ when studying the characteristics of the disease in different population groups.

Changes in occupational performance should also be stressed with regards to remunerated work. Similar to this research, there is another study ${ }^{29}$ using a qualitative methodology to learn about the reality of persons with fibromyalgia with regards to labor and its negative effect on performance, particularly because of the physical effort involved. Along these lines, other studies $^{26,30,31}$ with results similar to ours conclude that most individuals diagnosed with fibromyalgia are on sick leave or unemployed (sometimes against their will), but if they are working, they will need shorter workdays or a change of job. ${ }^{27,} 32,33$ This requires understanding and support by peers as a key ingredient to be able to keep their jobs. This was also evidenced in another study which showed that most people diagnosed with fibromyalgia fail to report their condition for fear of rejection. Although, those who report their condition say that they do experience more support and improved work environment. ${ }^{28}$

Another finding included that the activities that what the participants valued the most were household chores, such as cleaning, cooking, or selfcare. These are the activities they spend more time on every day, and need to restructure them, as was also the case in other studies. ${ }^{30,34}$ These studies compare the intervention with three different groups of people diagnosed with fibromyalgia, and in all of them this is a common denominator: the population studied modified their routines. In general, most of the people affected in our study are females, which in addition lost their role as housewives, so they feel vulnerable because society blames them for not being able to do their job. This was evidenced in another study, ${ }^{35}$ that justified this exclusion behavior based on cultural and historical reasons in global and neoliberal environments.

In terms of leisure, these activities seem to be neglected and their daily life is limited to selfcare and household chores, and eventually, if pain are fatigue are not too extreme, they may have some recreational activities. The result is occupational alienation since they are unable to enjoy enriching activities and their option are now fewer, sometimes leading to less satisfactory activities -as illustrated in other studies- ${ }^{36,} 37$; the main cause of occupational alienation is the passive role endured by the individual diagnosed with fibromyalgia, particularly with regards to his/her participation in various activities.

A common factor that is also a cause of the occupational performance issues discussed in our study is fatigue and constant moderate pain, which in consistent with the reports from other studies $^{26,38}$; this situation means that they go out of their homes less frequently or adapt their walks. One study ${ }^{39}$ measured the gait characteristics in this population and identified reduced speeds and shorter distances traveled by a group of women with fibromyalgia, as contrasted against another undiagnosed group. 
The second finding is consistent with the presence and interaction of the participants in the social fabric, including visiting healthcare centers. We stress the importance of bonding with family members and friends in order to expand their social relationships and feel more independent. As reported in another study ${ }^{40}$ conducted in elderly disabled individuals, this results in improved health conditions. In our study, similar to other studies, ${ }^{26,30,33,41}$ families do provide support to these individuals, although in some cases the relationships are difficult and sometimes are even lost. With regards to the community, sometimes they feel like socially excluded and discriminated victims, leading to stigmatization; this is consistent with another research study, ${ }^{42}$ that reflected an even worse situation in case of males, probably due to a lower prevalence and the psychosomatic component of the disease, in addition to the cultural component by the mere fact of being a male.

Moreover, in our study - and other similar studies, ${ }^{26,30,42}$ the constant visits to the doctor and the feeling of not being able to recover from the disease, causes such frustration that leads them to repeated complains about the care received, and the need to become members of patient Associations to feel that society understands and supports them.

\section{Study limitations}

There is a limitation in terms of being able to generalize the conclusions; this was not the intent of the study, but rather to focus on considering similar settings or environments to which these conclusions may be applicable.

\section{Future lines of research}

After this analysis of the reality of occupational performance of individuals with a diagnosis of fibromyalgia, we suggest:

- Undertaking similar studies with comparable groups, based on the time elapsed since the initial diagnosis.

- Studies limited specifically to females, since most patients diagnosed with this condition are women.

\section{Conclusion}

The conclusions respond to the objectives of the research:

Following the diagnosis of fibromyalgia, patients usually quit their jobs or school, they no longer participate in recreational activities, share with the community or friends. They also experience difficulty to carry out other activities such as reaching for objects, walking, and moving around the neighborhood. This is the result of impaired motor and executive skills, generalized pain, chronic fatigue, and changes in their routines.

In terms of their environments, they make changes at home and go out less and for shorter periods of time. Socially they join patient associations and sometimes get full support from relatives or friends, or on the contrary, they decide to breakup close ties.

\section{Financing}

No grants or funding from pharmaceutical companies were received. 


\section{Disclosures}

The authors have no conflicts of interest to disclose.

\section{Acknowledgments}

To the participants and Associations (ACOFIFA, AFFINOR and FIBROARTEIXO) for helping us to conduct this research project.

\section{References}

1. OMS. Constitución de la Organización Mundial de la Salud. [Internet]. NY. 2006 [acceso: 23/12/2017]; Sup: 20. Disponible: http://www.who.int/governance/eb/who constitution sp.pdf.2.

2. World Health Organization. Global health improvement and WHO: shaping the future. Lancet. 2003;362(9401):2083-8.3.

3. Gavidia V, Talavera M. La construcción del concepto de salud. Didact Cienc Exp Soc. 2012;10(26):161-75, http://dx.doi.org/10.7203/dces.26.1935.4.

4. World Health Organization [acceso: 22/12/2017]. Disponible: http://www.who.int/healthpromotion/Milestones HealthPromotion 0\%0A5022010.pdf, 2009.

5. American Occupational Therapy Association. Occupational therapy practice framework: domain and process. Am J Occup Ther. 2014; 68 (Sup 1):1-48, http://dx.doi.org/10.5014/ajot.2014.682006.

6. Aguilar-Parra JM, Padilla D, Manzano A. Importancia de la ocupación en el desarrollo del mayor y su influencia en su salud. Int J Dev Ed Psychol. 2016; 1:245-54, http://dx.doi.org/10.17060/ijodaep.2016.n1.v1.232.

7. Definitions occupational therapy [sede web]. Londres: World Federation Occupational Therapists;2013[acceso:23/12/2017].Disponible: http://www.wfot.org/aboutus/aboutoccupationaltherapy/definitionofoccupationaltherapy.asp $\mathrm{x}$.

8. Plata R. Intervención centrada en la persona, basada en la ocupación. Norte Salud Ment. 2012; 10(44):62-71.

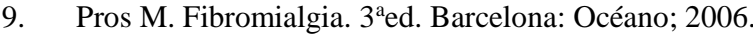

10. Munguía D, Legaz A, Alegre C. Guía de práctica clínica sobre el síndrome de Fibromialgia para profesionales de salud.Madrid: Elsevier; 2007.

11. Ministerio de Sanidad Política Social e Igualdad. Fibromialgia. Madrid: Ministerio Sanidad Política Social e Igualdad. 2011 [acceso: 24/12/2017]. Disponible: https://www.msssi.gob.es/profesionales/prestacionesSanitarias/publicaciones/docs/fibromial gia.pdf.

12. Martínez M. Ciencia y Clínica de la Fibromialgia. México: Panamericana; 2012.

13. Pérez-de-Heredia M, Huertas E, Sánchez-Camarero C,Pérez-Corrales J, Fernández de-lasPeñas C. The occupationalprofile of women with fibromyalgia syndrome. Occup Ther Int. 2015;23(2):132-42, http://dx.doi.org/10.1002/oti.1418.14..

14. Pérez de Heredia-Torres M, Huertas-Hoyas E ,Máximo-Bocanegra N, Palacios-Ceña D, Fernández-De-Las-Pe nas C. Cognitive performance in women with fibromyalgia: a casecontrol study. Aust Occup Ther J.2016; 63(5):329-37, http://dx.doi.org/10.1111/14401630.12292.

15. Perrot S, Winkelmann A, Dukes E, Xu X, Schaefer C, Ryan K, et al. Characteristics of patients with fibromyalgia in France and Germany. Int J Clin Pract Suppl. 2010; 64(8):1100-8, http://dx.doi.org/10.1111/j.1742-1241.2010.02418.x. 
16. Thompson JM, Luedtke CA, Oh TH, Shah ND, Long KH, King S, et al. Direct medical costs in patients with fibromyalgia. Am J Phys Med Rehabil. 2011; 90(1):40-6, http://dx.doi.org/10.1097/PHM.0b013e3181fc7ff3.

17. Quintana A, Montgomery W. Metodología de Investigación Científica Cualitativa. Lima: Universidad Nacional Mayor de San Marcos; 2006.

18. Verd JM, Lozares C. Introducción a la Investigación Cualitativa. Madrid: Síntesis; 2016.

19. Hernández R, Fernández C, Baptista P. Metodología de la investigación. 6aed México: Graw Hill; 2014.

20. Kielhofner G. Fundamentos conceptuales de Terapia Ocupacional. Buenos Aires: Panamericana; 2006.

21. Martínez-Salgado C. Muestreo en investigación cualitativa. Cien Saude Colet. 2012; 17(3):613-9, http://dx.doi.org/10.1590/S1413-81232012000300006.

22. Arias MM, Giraldo CV. Rigor científico en la investigación cualitativa. Invest Educ Enferm. 2011; 29(3):500-14.

23. Lee J-W, Lee K-E, Park D-J, Kim S-H, Nah S-S, Lee JH, et al. Determinants of quality of life in patients with fibromyalgia: a structural equation modeling approach. PLoS One.2017; 12(2):e0171186, http://dx.doi.org/10.1371/journal.pone.0171186.

24. Magnavita N, Garbarino S. Sleep, health and wellness at work: a scoping review. Int J Environ Res Public Health. 2017; 14(11):1347, http://dx.doi.org/10.3390/ijerph14111347.

25. Ramlee F, Sanborn AN, Tang NKY. What sways people's judgment of sleep quality? A quantitative choice-making study with good and poor sleepers. Sleep. 2017; 40(7):1-13, http://dx.doi.org/10.1093/sleep/zsx091.

26. Triviño A [acceso: 01/05/2018]. Disponible en: http://hdl.handle.net/10045/75156, 2017.

27. Arnold LM, Crofford LJ, Mease PJ, Burgess SM, Palmer SC, Abetz L, et al. Patient perspectives on the impact of fibromyalgia. Patient Educ Couns. 2008; 73(1):114-20, http://dx.doi.org/10.1016/j.pec.2008.06.005.

28. Jacobson SA, Simpson RG, Lubahn C, Hu C, Belden CM, Davis KJ, et al. Characterization of fibromyalgia symptoms inpatients 55-95 years old: a longitudinal study showing symptom persistence with suboptimal treatment. Aging Clin Exp Res. 2015; 27(1):75-82, http://dx.doi.org/10.1007/s40520-014-0238-7.

29. Marrero-Centeno J, Moreno-Velázquez I, Sánchez-Cardona I. Fibromialgia en Trabajo: explorando su Impacto en el Desempeño Laboral. Rev Inter Psicol Ocup. 2018; 36(2):8-21, http://dx.doi.org/10.21772/ripo.v36n1a01.

30. Collado A, Gómez E, Coscolla R, Sunyol R, Solé E, Rivera J, et al. Work, family and social environment in patients with Fibromyalgia in Spain: an epidemiological study: EPIFFAC study. BMC Health Serv Res. 2014; 14(1):1-10, http://dx.doi.org/10.1186/s12913-0140513-5.

31. Martí T, Llordés M, Custal M, López G, Martínez S. Perfil de pacientes con fibromialgia que acuden a los centros de atención primaria en Terrassa. Reumatol Clin. 2017; 13(5):2527, http://dx.doi.org/10.1016/j.reuma.2016.05.008.

32. Tomas-Carus P, Branco JC, Raimundo A, García J, Sousa PM, Biehl-Printes C. Relacão entre a dor generalizada e o limiar de tolerância à dor nos pontos sensíveis em mulheres portuguesas com fibromialgia: impacto sobre a vida diária. Acta Reumatol Port. 2015; 40(3):254-61. Disponible: http://hdl.handle.net/10362/22384

33. Retamal SG, López RB, Zepeda LD. Estudio correlacional sobre funcionamiento familiar y severidad de síntomas en pacientes con diagnóstico de fibromialgia en una muestra de participantes voluntarios de nacionalidad Chilena. Rev Psicot Rel Inte Soc. 2017; 13(35):53-68.

34. Mortensen J, Kristensen LQ, Brooks EP, Brooks AL. Women with fibromyalgia's experience with three motion-controlled video game consoles and indicators of symptom severity and performance of activities of daily living. Disabil Rehabil Assist Technol. 2015; 10(1):61-6, http://dx.doi.org/10.3109/17483107.2013.836687.

35. Montesó-Curtó P, Rosselló L. Compartir experiencias, combatir el dolor. Una visión de la fibromialgia desde el ámbito bio-psico-social. Tarragona: Universidad Rovira i Virgili; 2017.

36. Moruno P, Fernández P. Análisis teórico de conceptos, privación, alienación y justicia ocupacional. TOG (A Coruña).2012; 6 (mongrafía):44-68.

37. Hernández MA, Álvarez JS. El ocio punto de inclusión o exclusión. una mirada crítica. II Congreso Desigualdad Social, Económica y Educativa del Siglo XXI [Internet]. 2017 [acceso:02/05/2018];449-62.Disponible: http://www.eumed.net/libros-gratis/actas/2017/desigualdad/33-el-ocio-como-punto-deinclusion.pdf. 
38. Cabrera V [acceso: 01/05/2018]. Disponible: http://hdl.handle.net/11000/4518, 2017.

39. Costa IS, Gamundí A, Miranda JGV, França LGS, De Santana CN, Montoya P. Altered functional performance in patients with fibromyalgia. Front Hum Neurosci. 2017;11:1-9, http://dx.doi.org/10.3389/fnhum.2017.00014.

40. Cezar DM, Figueiredo V, Ferigato S, Agostini R. Personas con discapacidad y sus roles ocupacionales. Rev Chil Ter Ocup. 2016; 16(2):107-17, http://dx.doi.org/10.5354/07195346.2016.44755.

41. Fernández E. La fibromialgia como un problema de regulación del estrés [Tesis doctoral]. Elche: Universidad Miguel Hernández; 2017 [acceso: 02/05/2018]. Disponible: http://hdl.handle.net/11000/4459.

42. Vásquez LF [acceso: 02/05/2018]. Disponible: http://hdl.handle.net/11522/8017, 2017. 